\title{
Dawn of the Dead: \\ A Student Narrative on Collective Classrooms
}

\section{Fernando Janer ${ }^{1}$}

The following narrative analyzes the author's experiences as a student of Social Work in a collectively facilitated seminar. This critique will be mainly focused on the actual administration of participation in the classroom, and how this administration is regularly equivalent to the suppression of meaningful dialogue. This critique will also consider student participation in learning more broadly. Core social work values, as well as practical experience with egalitarianism, suggest that the clearer means of mending this situation is through the strengthening of decentralized facilitation in collective classrooms. [Article copies available for a fee from The Transformative Studies Institute. E-mail address: journal@transformativestudies.org Website: http://www.transformativestudies.org (C2012 by The Transformative Studies Institute. All rights reserved.]

KEYWORDS: Student Participation, Collectives, Mutual Aid, Social Work, Pedagogy of the Oppressed.

In addition to the life-death cycle basic to nature, there is almost an unnatural living death: Life which is denied its fullness.

Paulo Freire

The social work student is not dead. The student reflects critically on lua ${ }^{1}$ environment, personal skills, and professional experience. The student acts according to ethical principles and political commitments. Together with other students, the student organizes wellness days, buses to political rallies, and participates in representative committees. Remarkably, the social work student balances work, internship, school, and family. The student reads, writes, makes presentations, and even participates in class.

\footnotetext{
${ }^{1}$ Address correspondence to: Fernando Janer Sánchez, HC-01 Box 8210, Toa Baja, PR 00949 ; tel: 939-245-4272 ; e-mail: fernandojaner@gmail.com.
} 